\title{
Our Definition of Propeller Flaps and Their Classification
}

\author{
Marco Pignatti, MD, FEBOPRAS ${ }^{1}$ Rei Ogawa, MD, PhD, FACS ${ }^{2}$ Musa Mateev, MD, PhD 3 \\ Alexandru V. Georgescu, MD, PhD ${ }^{4}$ Govindasamy Balakrishnan, MS, MCh (Plastic), FRCS (England), \\ D.Sc (Hon) ${ }^{5}$ Shimpei Ono, MD, PhD ${ }^{2}$ Tania Cubison, MBBS, FRCS (Plast) ${ }^{6}$ Valentina Pinto, MD, PhD ${ }^{1}$ \\ Salvatore D’Arpa, MD, $\mathrm{PhD}^{7}$ Isao Koshima, MD, $\mathrm{PhD}^{8}$ Hiko Hyakusoku, MD, $\mathrm{PhD}^{2}$ \\ Geoffrey G. Hallock, MD ${ }^{9}$
}
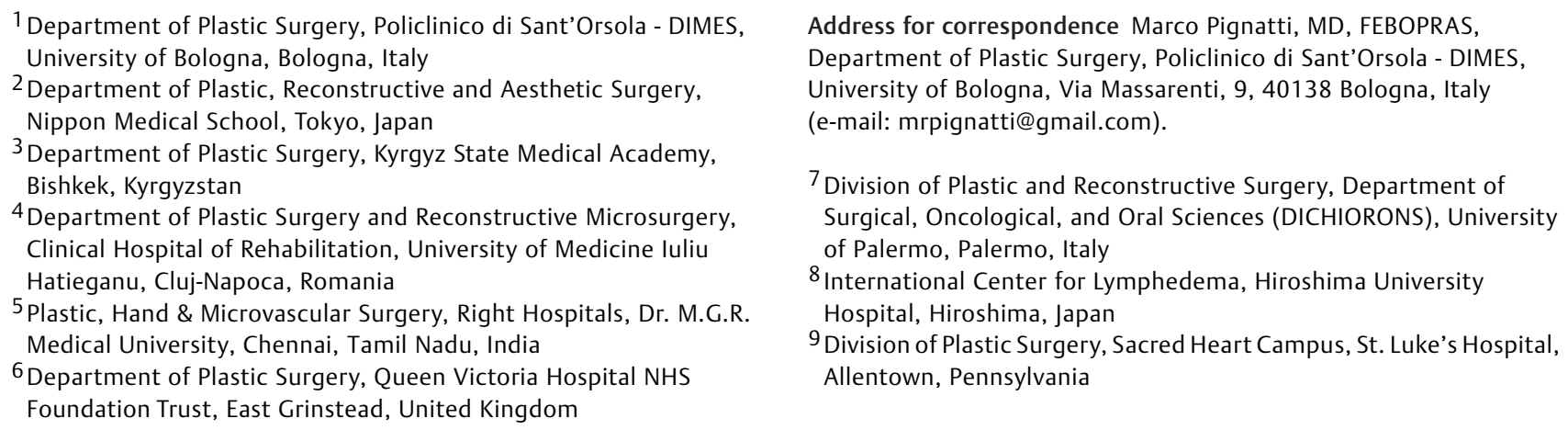

Semin Plast Surg 2020;34:139-144.

\begin{abstract}
The term propeller flap was introduced for the first time by Hyakusoku to define an island flap, based on a subcutaneous pedicle hub, that was rotated 90 degrees to correct scar contractures due to burns. With the popularization of perforator flaps, the propeller movement was applied for the first time to a skin island vascularized only by an isolated perforator, and the terms propeller and perforator flap were used together. Thereafter, the surgical technique of propeller flaps evolved and new applications developed. With the "Tokyo consensus," we proposed a definition and a classification schema for propeller flaps. A propeller flap was defined as an "island flap that reaches the recipient site through an axial rotation." The classification included the SPP (SPP) flap, the perforator pedicled propeller (PPP) flap, and the supercharged PPP (SCP) flap. A recent update added a new category, the axial pedicled propeller (APP) flap. Here we propose our updated and comprehensive classification of propeller flaps, taking into account the previous classification and subsequent publications. Based on their

Keywords

- propeller flap

- definition

- classification

- update vascular pedicle, we consider the following five types of propellers: (1) SPP flap, 2. PPP flap, its subtype (2a) SCP flap, (3) APP flap, (4) muscle propeller flap, and (5) chimeric propeller flap. The variables that can be taken into account in the classification are as follows: type of nourishing pedicle, degrees of skin island rotation, position of the nourishing pedicle, artery of origin of the pedicle, and flap shape.
\end{abstract}

The term propeller flap was introduced for the first time by Hyakusoku to define island flaps, based on a subcutaneous pedicle hub, that were rotated 90 degrees to correct scar contractures due to burns. ${ }^{1}$ With a better understanding of the angiosome concept ${ }^{2-4}$ and the superior role of perforator vessels in skin flap perfusion, ${ }^{5}$ new applications using pedicled
Issue Theme Propeller Flaps; Guest Editors: Geoffrey G. Hallock, MD, Marco Pignatti, MD
Copyright (C) 2020 by Thieme Medical Publishers, Inc., 333 Seventh Avenue, New York, NY 10001, USA. Tel: +1(212) 760-0888.
DOI https://doi.org/ 10.1055/s-0040-1715158. ISSN 1535-2188. 
or local perforator flaps were soon developed, ${ }^{6}$ including the propeller movement. $^{7}$

Based on this anatomical knowledge, Hallock applied the propeller movement of a skin island vascularized only by an isolated perforator, over the adductor compartment of the thigh, using the terms propeller and perforator flap together for the first time. ${ }^{8}$

The subsequent work of Teo was of great importance in popularizing the use of propeller flaps for soft tissue reconstruction. $^{9}$

The presentations in propeller flaps sessions during subsequent perforator flap courses or instructional meetings contributed to an exponential increase in interest in this concept. Concurrently, a few scattered publications started to appear in the English literature describing the propeller flap experiences of different groups, in the lower limb, ${ }^{10-13}$ and in other parts of the body, ${ }^{14,15}$ from the upper limb ${ }^{16,17}$ to the face ${ }^{18-22}$ and to the trunk..$^{23,24}$

At the First Tokyo Meeting on Perforator and Propeller Flaps, in 2009, faculty and colleagues gathered from all around the world to present their experiences. On that occasion, they proposed both a definition and a classification schema for propeller flaps, as this was absent until then. ${ }^{25}$ This was known as the "Tokyo consensus" and stated that a propeller flap can be defined as an "island flap that reaches the recipient site through an axial rota- tion." This classification included three kinds of propeller flaps that differed on the basis of the nourishing pedicle: the subcutaneous pedicled propeller (SPP) flap, the perforator pedicled propeller (PPP) flap, and the supercharged PPP (SCP) flap.

A recent paper proposed an alteration of this classification of propeller flaps to include new flap variations that have evolved. ${ }^{26}$ One new category was called the "axial pedicled propeller" (APP) flap and included island flaps that rotate on their pedicle 90 to 180 degrees. Instead of being nourished by a perforator or by a subcutaneous "random" pedicle, these are vascularized instead by a recognized axial vessel (-Fig. 1).

A slightly different classification concept was proposed by Ayestaray et al in 2011. ${ }^{27}$

According to their schema, four subtypes are differentiated on the basis of their unique vascular pedicle: PPP flaps, SPP flaps, muscular pedicled propeller (MPP) flaps, and vascular axial-pedicled propeller (VPP) flaps perforator flaps.

An overview of these salient points has led to our updated classification of propeller flaps ( - Fig. 2, - Table 1):

1. SPP flaps.

2. PPP flaps.

2a. SCP flaps.

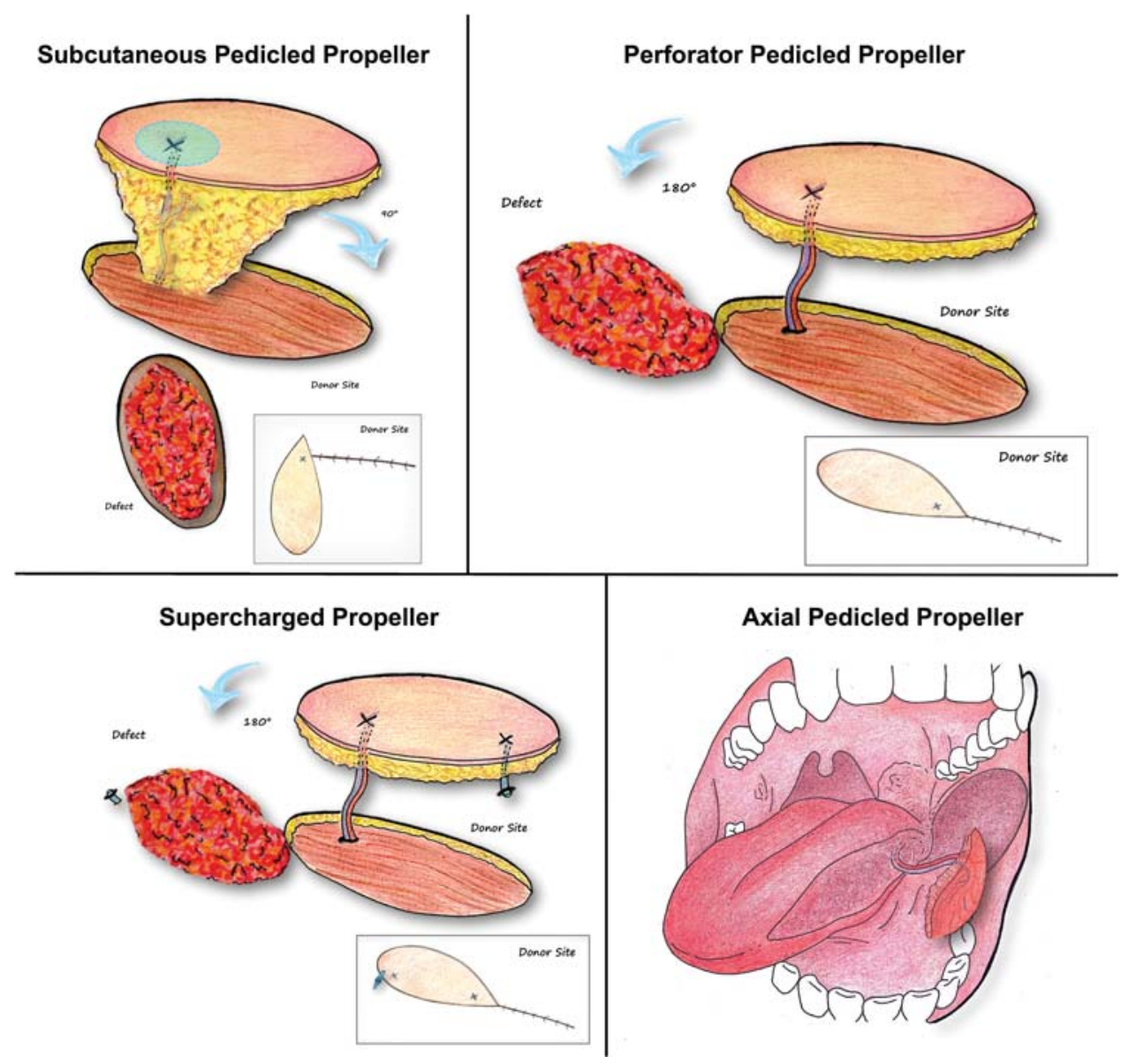

Fig. 1 Tokyo classification updated. Four types of propeller flaps are classified on the basis of their nourishing pedicle: (1) subcutaneous pedicle propeller flaps, (2) perforator pedicled propeller flaps, (3) supercharged perforator pedicled propeller flaps, and (4) axial pedicled propeller flaps. 


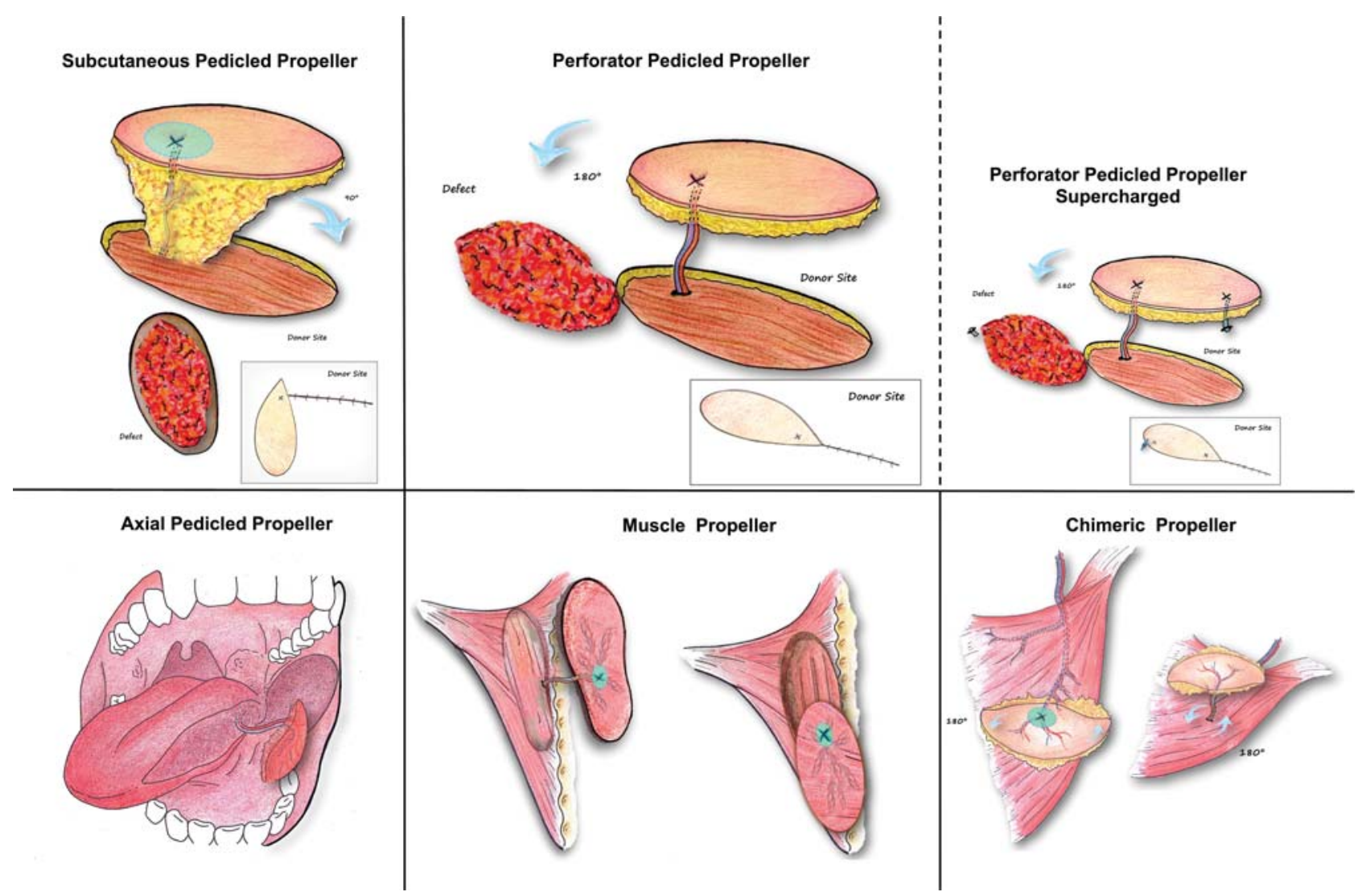

Fig. 2 New comprehensive classification of propeller flaps. Five types of propeller flaps are classified on the base of their nourishing pedicle: (1) subcutaneous pedicle propeller flaps, (2) perforator pedicled propeller flaps and its subtype (2a) supercharged perforator pedicled propeller flaps, (3) axial pedicled propeller flaps, (4) muscle propeller flaps, and (5) chimeric propeller flap.

3. VPP flaps.

4. MPP flaps.

5. Chimeric propeller flaps.

\section{Classification of Propeller Flaps Based on Their Vascular Pedicle}

The source of the nourishing pedicle to the given propeller flap is probably the most important variable for the classification of propeller flaps.

\section{Subcutaneous Pedicle Propeller Flaps}

This type of propeller flap has limited usefulness depending on specific conditions and anatomical sites. For example, burn contractures of mild or sometimes even moderate severity, especially if involving the axilla or elbow, can be released and covered with these flaps using the remaining unburned skin, as was originally described by Hyakusoku. ${ }^{1}$ Several variations of this technique may be applied to better optimize the result. ${ }^{28-30}$

The perineum is another region where this subtype of propeller flap is most useful as exemplified by the "lotus flaps." ${ }^{31}$ In some instances, propeller flaps of the facial artery are also better raised with this technique, especially when the arterial perforator and the venous perforator lie at some distance from one another, as is characteristic.

\section{Perforator Pedicled Propeller Flaps}

The majority of flaps in the literature that are called "propeller flaps" belong to this category. Their range of rotation can reach 180 degrees, as long as the perforator pedicle is followed and isolated enough toward the main source vessel. The most popular PPP flaps arise in either the trunk, such as those based on internal mammary artery perforators, ${ }^{32}$ lateral intercostal artery perforators, or lumbar perforators, or on the lower extremity, ${ }^{33,34}$ such as those based on posterior tibial and peroneal perforators. ${ }^{10-12}$

As recognized in the Gent consensus and subsequent updates, ${ }^{35}$ perforators can reach the skin either directly through a septum or indirectly through muscle or some other tissue medium. Thus, PPP flaps can be further subcategorized into the following:

1. Axial or direct cutaneous type (e.g., superficial circumflex iliac artery perforator).

2. Septocutaneous type (e.g., radial forearm).

3. Musculocutaneous type (e.g., thoracoacromial).

\section{Supercharged Perforator Pedicled Propeller Flaps}

This subtype is rarely used, and that too mostly for the prevention of complications. A microanastomosis is required, and therefore this makes the overall procedure much more complicated. The size of the flap can be extended to include the next perforasome by arterial supercharging. ${ }^{36}$ 
Table 1 New comprehensive classification of propeller flaps

\begin{tabular}{|c|c|c|c|c|c|c|c|}
\hline \multicolumn{2}{|c|}{ Flap type } & \multirow{2}{*}{$\begin{array}{l}\text { Pedicle } \\
\text { Random } \\
\text { (perforator not } \\
\text { visualized) }\end{array}$} & \multirow{2}{*}{$\begin{array}{l}\text { Rotation } \\
\text { Up to } \\
90 \text { degrees }\end{array}$} & \multirow{2}{*}{$\begin{array}{l}\begin{array}{l}\text { Vessel of } \\
\text { origin }\end{array} \\
\text { Not known }\end{array}$} & \multirow{2}{*}{$\begin{array}{l}\begin{array}{l}\text { Dissection } \\
\text { technique }\end{array} \\
\text { Macroscopic }\end{array}$} & \multirow{2}{*}{$\begin{array}{l}\text { Details } \\
\text { The first defined } \\
\text { as propeller }\end{array}$} & \multirow{2}{*}{$\begin{array}{l}\text { Example } \\
\text { Elbow in burns } \\
\text { (first described) } \\
\text { Lotus flap } 1\end{array}$} \\
\hline 1 & $\begin{array}{l}\text { Subcutaneous } \\
\text { pedicled } \\
\text { propeller flap }\end{array}$ & & & & & & \\
\hline 2 & $\begin{array}{l}\text { Perforator } \\
\text { pedicled } \\
\text { propeller flap }\end{array}$ & $\begin{array}{l}\text { Dissected } \\
\text { perforator }\end{array}$ & $\begin{array}{l}\text { Up to } \\
180 \text { degrees }\end{array}$ & $\begin{array}{l}\text { Plausible or } \\
\text { visualized }\end{array}$ & $\begin{array}{l}\text { Magnification } \\
\text { needed }\end{array}$ & The one mostly used & $\begin{array}{l}\text { Propellers } \\
\text { of the leg }{ }^{11}\end{array}$ \\
\hline $2 a$ & $\begin{array}{l}\text { Supercharged } \\
\text { perforator } \\
\text { pedicled } \\
\text { propeller flap }\end{array}$ & $\begin{array}{l}\text { Dissected } \\
\text { perforator }+ \text { extra } \\
\text { vein or artery }\end{array}$ & $\begin{array}{l}\text { Up to } \\
180 \text { degrees }\end{array}$ & $\begin{array}{l}\text { Plausible or } \\
\text { visualized }\end{array}$ & $\begin{array}{l}\text { Magnification } \\
\text { needed }+ \\
\text { Microsurgical } \\
\text { anastomosis }\end{array}$ & $\begin{array}{l}\text { In case of congestion } \\
\text { (venous anastomosis) } \\
\text { or for larger flaps } \\
\text { (artery/vein) }\end{array}$ & Trunk, limbs ${ }^{28}$ \\
\hline 3 & $\begin{array}{l}\text { Axial pedicled } \\
\text { propeller flaps }\end{array}$ & $\begin{array}{l}\text { Known } \\
\text { axial vessel }\end{array}$ & $\begin{array}{l}\text { Up to } \\
180 \text { degrees }\end{array}$ & $\begin{array}{l}\text { Known } \\
\text { (constant)/ } \\
\text { visualized }\end{array}$ & $\begin{array}{l}\text { Magnification } \\
\text { needed }\end{array}$ & $\begin{array}{l}\text { Evolution of } \\
\text { axial flaps }\end{array}$ & $\begin{array}{l}\text { Lingual artery } \\
\text { propeller }^{38}\end{array}$ \\
\hline 4 & $\begin{array}{l}\text { Muscle } \\
\text { propeller flaps }\end{array}$ & $\begin{array}{l}\text { Main vessel or } \\
\text { branch to the } \\
\text { muscle }\end{array}$ & $\begin{array}{l}\text { Up to } \\
180 \text { degrees }\end{array}$ & $\begin{array}{l}\text { Known } \\
\text { (constant)/ } \\
\text { visualized }\end{array}$ & $\begin{array}{l}\text { Magnification } \\
\text { advisable }\end{array}$ & $\begin{array}{l}\text { Evolution of } \\
\text { Muscular flaps }\end{array}$ & $\begin{array}{l}\text { Trapezius } \\
\text { muscle } \\
\text { propeller }^{31}\end{array}$ \\
\hline 5 & $\begin{array}{l}\text { Chimeric } \\
\text { propeller flaps }\end{array}$ & $\begin{array}{l}\text { Vessel to the first } \\
\text { tissue + dissected } \\
\text { perforator }\end{array}$ & $\begin{array}{l}180 \text { degrees }+ \\
180 \text { degrees }\end{array}$ & $\begin{array}{l}\text { Known }+ \\
\text { visualized }\end{array}$ & $\begin{array}{l}\text { Magnification } \\
\text { needed }\end{array}$ & $\begin{array}{l}\text { Bone or muscle } \\
\text { flap + perforator } \\
\text { pedicled propeller }\end{array}$ & Razor flap ${ }^{40}$ \\
\hline
\end{tabular}

Venous superdrainage may be required for perceived flap congestion, but it is also used routinely for some flaps or surgical settings as a preventive measure to lessen the risk and thereby also to avoid the need for a hospital admission. ${ }^{37}$

\section{Axial Pedicled Propeller Flaps}

This is a newer category that includes only island flaps that are based on an axial vessel that enters the flap perpendicular to its surface, without ever being a deep fascia perforator. Reach to the recipient site is with a propeller or rotation movement. To reiterate, the pedicle is neither a perforator nor subcutaneous tissues but a clearly isolated vessel.

Prior propeller flaps that have been described in the literature and are considered to fall into this category are the STAAP (supratrochlear artery axial propeller) and the DLAAP (deep lingual artery axial propeller) flaps. ${ }^{26,38}$ This inclusion is not without criticism. For example, the propeller flap based on the supratrochlear artery is considered by some to be no different than any other perforator-based propeller flaps, as the nourishing vessel pierces the corrugator and frontalis muscles before entering the subcutaneous layer and therefore in fact is a musculocutaneous perforator.

It is certainly more difficult to classify the propeller flap DLAAP. First, the flap consists only of muscle and mucosa, and, second, the deep lingual vessel enters the flap in a perpendicular fashion without ever perforating any other tissue such as fascia. Thus, we must accept this flap variation to be part of a different class of propeller flaps, that is, the APP flaps, as proposed.

\section{Muscle Propeller Flaps}

Although in the beginning of propeller flap history, all propeller flaps were skin flaps, over the years, propeller flaps that are comprised of other tissues have been described. Because the Tokyo consensus defined a propel- ler flap as an "island flap that reaches the recipient site through an axial rotation," not only skin island flaps but also island flaps of fascia, subcutaneous tissue, mucosa, and even muscle can be called propeller flaps if rotated on their axis, as exemplified by the already mentioned DLAAP flap. ${ }^{38}$ An example of the muscle pedicled propeller flap would be the trapezius muscle propeller flap, ${ }^{39}$ where a portion of the trapezius muscle was rotated 160 degrees on the axis of the dorsal scapular artery pedicle of the muscle.

\section{Chimeric Propeller Flap}

This is an evolution of the chimeric flap concept, which itself is defined as being composed of multiple independent tissues and connected only through branches of the same main vessel. When one or more of the components of the flap have a movement of rotation on the axis of their specific pedicle, but without a complete dissection back to the source vessel, then that part can be considered a propeller flap, and the entire complex can be named a chimeric propeller flap. Probably, the first description of this variation was by Cavadas and Teran-Saavedra, who called this a "razor flap." 40

The advantage of the chimeric propeller flap is even greater freedom of movement of the different components to allow simultaneous coverage of different defects or parts of the same defect, with tissues having different attributes (i.e., more malleable muscle to fill a deeper defect and then skin to facilitate superficial wound closure). ${ }^{41}$

\section{Classification of Propeller Flaps Based on Nonvascular Variables}

Sometimes, other characteristics of a propeller flap need to be described to allow a more complete understanding of how 


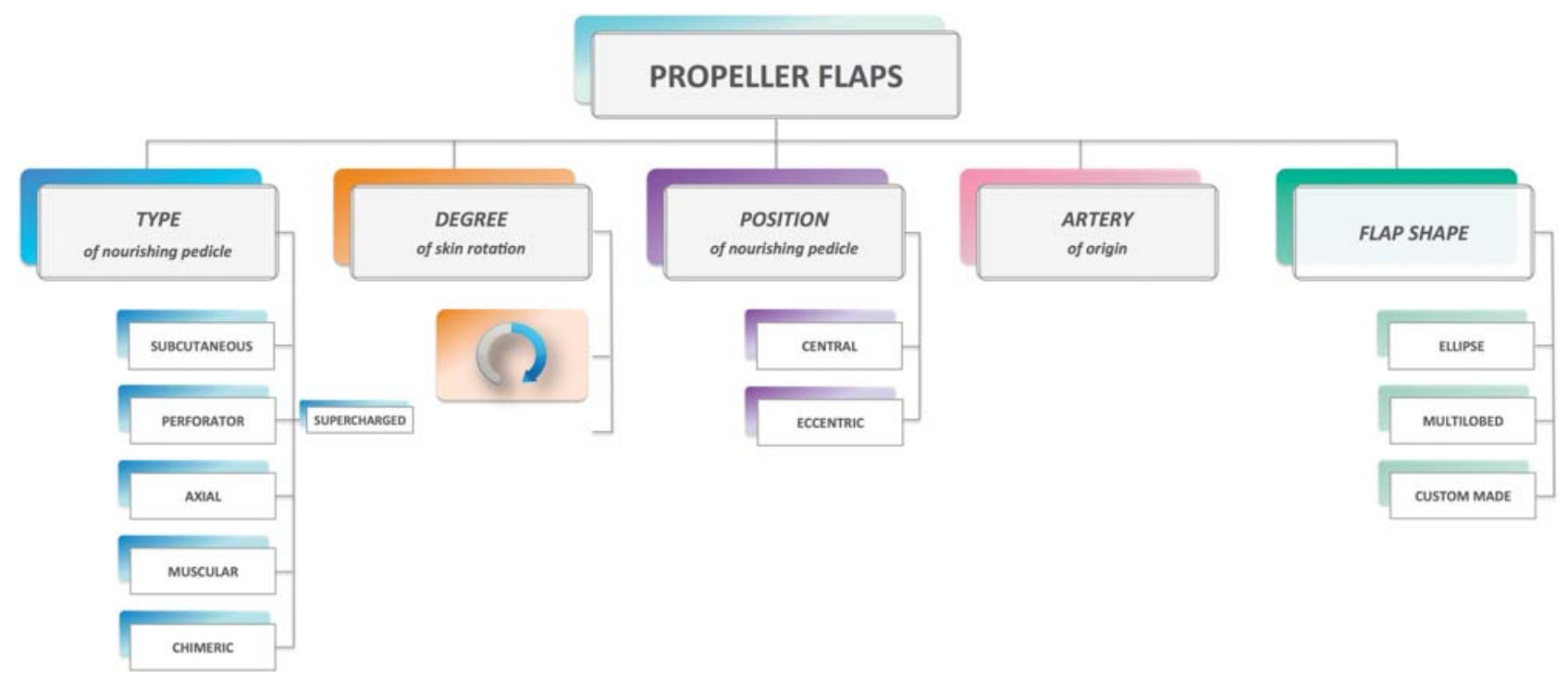

Fig. 3 Classification of propeller flaps based on all the variables: type of nourishing pedicle, degrees of skin island rotation, position of the nourishing pedicle, artery of origin of the pedicle, and flap shape.

the flap was designed and transposed to ensure that the methodology is sound, reliable, and safe (-Fig. 3).

\section{Degrees of Skin Island Rotation}

The degree of rotation of a propeller flap may vary up to 180 degrees, and the actual amount will depend on the position of the perforator in relation to the defect. This rotation will also depend on how the skin island is designed, which usually will be according to the expected distribution of the perforator branching pattern in the involved subcutaneous and subdermal tissues. ${ }^{42}$

\section{Position of the Nourishing Pedicle}

The nourishing vessel usually enters perpendicular to the undersurface of the flap either in the center (typically as would be a subcutaneous pedicled propeller flap for scar contractures) or, more frequently, in an eccentric position. The latter would be the more advantageous for local soft tissue reconstruction, as the larger portion of the skin island can be used to cover the defect while the minor paddle is either discarded (as in a 90-degree rotation) or used to resurface a portion of the major paddle donor site.

\section{Artery of Origin of the Pedicle}

In most cases, according to the body region and our knowledge of the normal vascular anatomy, the artery of origin of the perforators of that area could be reasonably hypothesized for each propeller flap. This is generally true for the perforator based propeller flaps but less precisely so for SPP flaps. In other anatomical areas, the contiguity of multiple source vessels, that give origin to several perforators, makes it difficult to precisely specify the vessel of origin of a given observed perforator. An example of this difficulty is the thoracic region in proximity to the axillary lines, where perforators of the intercostal vessels, thoracodorsal vessels, serratus branch, circumscapular, or lateral thoracic may easily be confused one with the other (although not always having negative clinical consequences when harvesting a propeller flap).

\section{Flap Shape}

As a consequence of the usually reliable perfusion of propeller flaps, the shape of the skin island may often freely mimic the shape of the defect. Thus, the flap configuration may vary from an ellipsoid island, bemultilobed, or completely custom-made to each defect.

\section{Conclusion}

This brief introduction has been intended to reiterate the historical development of the propeller flap, as we have witnessed. An updated definition of this concept and a classification schema that distinguishes between new and old variations of propeller flaps will surely open multiple points for discussion that hopefully will lead to even better improvements that can only enhance its versatility.

Conflicts of Interest

None declared.

Acknowledgment

This article is dedicated to the memory of Musa Mateev [1959-2020], a true pioneer in propeller flaps, who remained with us to make sure this issue was complete.

\section{References}

1 Hyakusoku H, Yamamoto T, Fumiiri M. The propeller flap method. Br J Plast Surg 1991;44(01):53-54

2 Taylor GI, Palmer JH. The vascular territories (angiosomes) of the body: experimental study and clinical applications. Br J Plast Surg 1987;40(02):113-141

3 Taylor GI. The angiosomes of the body and their supply to perforator flaps. Clin Plast Surg 2003;30(03):331-342, v 
4 Taylor GI, Pan WR. Angiosomes of the leg: anatomic study and clinical implications. Plast Reconstr Surg 1998;102(03):599-616, discussion 617-618

5 Blondeel PN, Van Landuyt KH, Monstrey SJ, et al. The "Gent" consensus on perforator flap terminology: preliminary definitions. Plast Reconstr Surg 2003;112(05):1378-1383, quiz 1383, 1516, discussion 1384-1387

6 Mardini S, Al-Mufarrej FM, Jeng SF, Wei FC. Free-style free flaps. In: Blondeel PN, Morris SF, Hallock GG, Neligan PC, eds. Perforator Flaps: Anatomy, Technique, \& Clinical Applications. Vol. 2, 2nd ed. St. Louis, MO: Quality Medical; 2013:1245-1260

7 Georgescu AV, Ivan O. Lambeau radial antibrachial en îlot basé sur des perforantes distales. A propos d'un cas clinique. Ann Chir Plast Esthet 2000;45(01):58-61

8 Hallock GG. The propeller flap version of the adductor muscle perforator flap for coverage of ischial or trochanteric pressure sores. Ann Plast Surg 2006;56(05):540-542

9 Teo TC. The propeller flap concept. Clin Plast Surg 2010;37(04): 615-626, vi

10 Masia J, Moscatiello F, Pons G, Fernandez M, Lopez S, Serret P. Our experience in lower limb reconstruction with perforator flaps. Ann Plast Surg 2007;58(05):507-512

11 Jakubietz RG, Jakubietz MG, Gruenert JG, Kloss DF. The 180degree perforator-based propeller flap for soft tissue coverage of the distal, lower extremity: a new method to achieve reliable coverage of the distal lower extremity with a local, fasciocutaneous perforator flap. Ann Plast Surg 2007;59(06):667-671

12 Pignatti M, Pasqualini M, Governa M, Bruti M, Rigotti G. Propeller flaps for leg reconstruction. J Plast Reconstr Aesthet Surg 2008;61 (07):777-783

13 Pignatti M, D’Arpa S, Cubison TCS. Novel fasciocutaneous flaps for the reconstruction of complicated lower extremity wounds. Tech Orthop 2009;24(02):88-95

14 D’Arpa S, Toia F, Pirrello R, Moschella F, Cordova A. Propeller flaps: a review of indications, technique, and results. BioMed Res Int 2014;2014:986829

15 D'Arpa S, Cordova A, Pignatti M, Moschella F. Freestyle pedicled perforator flaps: safety, prevention of complications, and management based on 85 consecutive cases. Plast Reconstr Surg 2011; 128(04):892-906

16 Georgescu AV, Matei I, Ardelean F, Capota I. Microsurgical nonmicrovascular flaps in forearm and hand reconstruction. Microsurgery 2007;27(05):384-394

17 Mateev MA, Ogawa R, Trunov L, Moldobaeva N, Hyakusoku H. Shape-modified radial artery perforator flap method: analysis of 112 cases. Plast Reconstr Surg 2009;123(05):1533-1543

18 D’Arpa S, Cordova A, Pirrello R, Moschella F. One-stage reconstruction of the nasal ala: the free-style nasolabial perforator flap. Plast Reconstr Surg 2009;123(02):65e-66e

19 Cordova A, D’Arpa S, Massimiliano T, Toia F, Moschella F. A propeller flap for single-stage nose reconstruction in selected patients: supratrochlear artery axial propeller flap. Facial Plast Surg 2014;30(03):332-341

20 D’Arpa S, Pirrello R, Toia F, Moschella F, Cordova A. Reconstruction of nasal alar defects with freestyle facial artery perforator flaps. Facial Plast Surg 2014;30(03):277-286

21 Cordova A, D’Arpa S, Moschella F. A new one-stage method for nose reconstruction: the supratrochlear artery perforator propeller flap. Plast Reconstr Surg 2012;129(03):571e-573e

22 D’Arpa S, Cordova A, Pirrello R, Moschella F. Free style facial artery perforator flap for one stage reconstruction of the nasal ala. J Plast Reconstr Aesthet Surg 2009;62(01):36-42

23 Ogawa R, Murakami M, Vinh VQ, Hyakusoku H. Clinical and anatomical study of superficial cervical artery flaps: retrospective study of reconstructions with 41 flaps and the feasibility of harvesting them as perforator flaps. Plast Reconstr Surg 2006; 118(01):95-101

24 Moshre S, Lee GK. Current applications of propeller aps in reconstruction of trunk wounds. Plast Aesthet Res 2017; 4:204-208

25 Pignatti M, Ogawa R, Hallock GG, et al. The "Tokyo" consensus on propeller flaps. Plast Reconstr Surg 2011;127(02):716-722

26 Toia F, D’Arpa S, Pignatti M, Noel W, Cordova A. Axial propeller flaps: a proposal for update of the "Tokyo consensus on propeller flaps". J Plast Reconstr Aesthet Surg 2017;70(06):857-860

27 Ayestaray B, Ogawa R, Ono S, Hyakusoku H. Propeller flaps: classification and clinical applications. Ann Chir Plast Esthet 2011;56(02):90-98

28 Murakami M, Hyakusoku H, Ogawa R. The multilobed propeller flap method. Plast Reconstr Surg 2005;116(02):599-604

29 Karki D, Ahuja RB. A review and critical appraisal of central axis flaps in axillary and elbow contractures. Burns Trauma 2017; $5: 13$

30 Karki D, Muthukumar V, Dash S. "Namaste flap": modification of subcutaneous pedicle propeller flaps in the reconstruction of postburn axillary and elbow contractures. Ann Plast Surg 2019;83 (06):636-641

31 Yii NW, Niranjan NS. Lotus petal flaps in vulvo-vaginal reconstruction. Br J Plast Surg 1996;49(08):547-554

32 Zanchetta F, Borg M, Troisi L. Reconstruction of a deep sternal wound with exposed pericardium using an IMAP propeller flap: a case report. Clin Case Rep 2019;7(12):2371-2374

33 Wishart KT, Fritsche E, Scaglioni MF. Reconstruction of a large pelvic defect by transfer of a quadruplet combination of pedicled flaps from the medial thigh using bilateral muscular gracilis flaps and bilateral vertical posteromedial thigh (vPMT) propeller flapsa case report. Microsurgery 2020;40(04):486-491

34 Wu, JCW, Chang, TNJ, Huang, JJ, Sachanandani, N, Cheng MH. Abstract: Obturator artery perforator propeller flap for scrotal and vulvar reconstruction. Plast Reconstr Surg Glob Open 2016;4 (9S):109-110

35 Blondeel PN, Van Landuyt K, Hamdi M, Monstrey SJ. Perforator flap terminology: update 2002. Clin Plast Surg 2003;30(03): 343-346, v

36 Chaput B, Bertheuil N, Grolleau JL, et al. Comparison of propeller perforator flap and venous supercharged propeller perforator flap in reconstruction of lower limb soft tissue defect: a prospective study. Microsurgery 2018;38(02):177-184

37 Kosutic D, Dutta P, Kieran I. Prophylactic venous supercharged radial collateral artery perforator propeller flap: improved outcome in perforator propeller flaps. J Reconstr Microsurg Open 2016;1:45-47

38 Cordova A, Toia F, D’Arpa S, Giunta G, Moschella F. A new mucosal propeller flap (deep lingual artery axial propeller): the renaissance of lingual flaps. Plast Reconstr Surg 2015;135(03): $584 \mathrm{e}-594 \mathrm{e}$

39 Meyerson J, O'Brien A, Calvin N, Chandawarkar R. A new propeller trapezius muscle flap for reconstruction of posterior trunk defects: an anatomic study and report of three cases. Microsurgery 2019;39(05):428-433

40 Cavadas PC, Teran-Saavedra PP. Combined latissimus dorsi-thoracodorsal artery perforator free flap: the "razor flap.". J Reconstr Microsurg 2002;18(01):29-31

41 Hallock GG. The chimeric propeller flap. Semin Plast Surg 2020;34 (03):207-209

42 Pignatti M, Pinto V, Dokerty Skogh AC, et al. How to design and harvest a propeller flap. Semin Plast Surg 2020;34(03): $152-160$ 